PNL-6507

DOE/HWP-50

UC-69

\title{
Waste Acid Detoxification and Reclamation: \\ Phase I - Project Planning and Concept Development
}

T. L. Stewart

T. M. Brouns

February 1988

Prepared for the U.S. Department of Energy under Contract DE-AC06-76RLO 1830

Pacific Northwest Laboratory

Operated for the U.S. Department of Energy

by Battelle Memorial Institute 


\section{DISCLAIMER}

This report was prepared as an account of work sponsored by an agency of the United States Government. Neither the United States Government nor any agency thereof, nor Battelle Memorial Institute, nor any or their employees, makes any warranty, expressed or implied, or assumes any legal liability or responsibility for the accuracy, completeness, or usefulness of any information, apparatus, product, or process disclosed, or represents that its use would not infringe privately owned rights. Reference herein to any specific commercial product, process, or service by trade name, trademark, manufacturer, or otherwise does not necessarily constitute or imply its endorsement, recommendation, or favoring by the United States Government or any agency thereof, or Battelle Memorial Institute. The views and opinions of authors expressed herein do not necessarily state or reflect those of the United States Government or any agency thereof, or Battelle Memorial Institute.

\section{PACIFIC NORTHWEST LABORATORY operated by \\ BATTELLE MEMORIAL INSTITUTE for the UNITED STATES DEPARTMENT OF ENERGY under Contract DE-AC06-76RLO 1830}

\begin{tabular}{|c|c|}
\hline \multicolumn{2}{|c|}{$\begin{array}{l}\text { Printed in the United States of America } \\
\text { Availabie from } \\
\text { National Technical Information Service } \\
\text { United States Department of Commerce } \\
5285 \text { Port Royal Road } \\
\text { 5pringfield, Virginia } 22161\end{array}$} \\
\hline \multicolumn{2}{|c|}{$\begin{array}{l}\text { NTIS Price Codes } \\
\text { Misrofiche A01 }\end{array}$} \\
\hline \multicolumn{2}{|c|}{ Printed Copy } \\
\hline Pages & $\begin{array}{l}\text { Price } \\
\text { Codes }\end{array}$ \\
\hline $001-025$ & $\mathrm{~A} 02$ \\
\hline $026-050$ & $\mathrm{~A} 03$ \\
\hline $051-075$ & A04 \\
\hline $076-100$ & A05 \\
\hline $101-125$ & AOS \\
\hline $126-150$ & $\mathrm{~A} 07$ \\
\hline $151-175$ & A08 \\
\hline $17 b-200$ & Ans \\
\hline 201.225 & A010 \\
\hline $226-250$ & A01T \\
\hline $251-275$ & $\mathrm{~A} 012$ \\
\hline $276-300$ & $\mathrm{~A} 013$ \\
\hline
\end{tabular}


PNL -6507

DOE/HWP-50

\section{WASTE ACID DETOXIFICATION AND RECLAMATION: PHASE I -PROJECT PLANNING AND CONCEPT DEVELOPMENT}

T. L. Stewart

T. M. Brouns

February 1988

Sponsored by the

U.S. DOE HAZARDOUS WASTE REMEDIAL ACTIONS PROGRAM

through the

Support Contractor office

Oak Ridge, Tennessee 37831 operated by

MARTIN MARIETTA ENERGY SYSTEMS, INC.

for the

U.S. DEPARTMENT OF ENERGY

Under Contract No. DE-AC05-840R21400

Pacific Northwest Laboratory

Richland, Washington 99352 


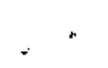

, 


\section{ABSTRACT}

The objectives of the Waste Acid Detoxification and Reclamation project are to develop processes for reducing the volume, quantity, and toxicity of metal-bearing waste acids. The primary incentives for implementing these types of waste minimization processes are regulatory and economic (that is, they meet requirements in the Resource Conservation and Recovery Act and reduce the cost for treatment, storage, and disposal). Two precipitation processes and a distillation process are being developed to minimize waste from fuel fabrication operations, which comprise a series of metal-finishing operations. Waste process acids, such as $\mathrm{HF}-\mathrm{HNO}_{3}$ etch solutions containing $\mathrm{Zr}$ as a major metal impurity and $\mathrm{HNO}_{3}$ strip solutions containing $\mathrm{Cu}$ as a major metal impurity, are detoxified and reclaimed by concurrently precipitating heavy metals and regenerating acid for recycle. Acid from a third waste acid stream generated from chemical milling operations will be reclaimed using distillation. This stream comprises $\mathrm{HNO}_{3}$ and $\mathrm{H}_{2} \mathrm{SO}_{4}$ which contains $U$ as the major metal impurity. Distillation allows $\mathrm{NO}_{3}^{-}$to be displaced by $\mathrm{SO}_{4}^{-2}$ in metal salts; free $\mathrm{HNO}_{3}$ is then vaporized from the U-bearing sulfate stream. Uranium can be recovered from the sulfate stream in a downstream precipitation step. These waste minimization processes were developed to meet Hanford's fuel fabrication process needs. However, precipitation and distillation operations are amenable to processes at other DOE facilities. 


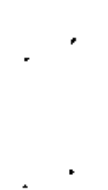




\section{CONTENTS}

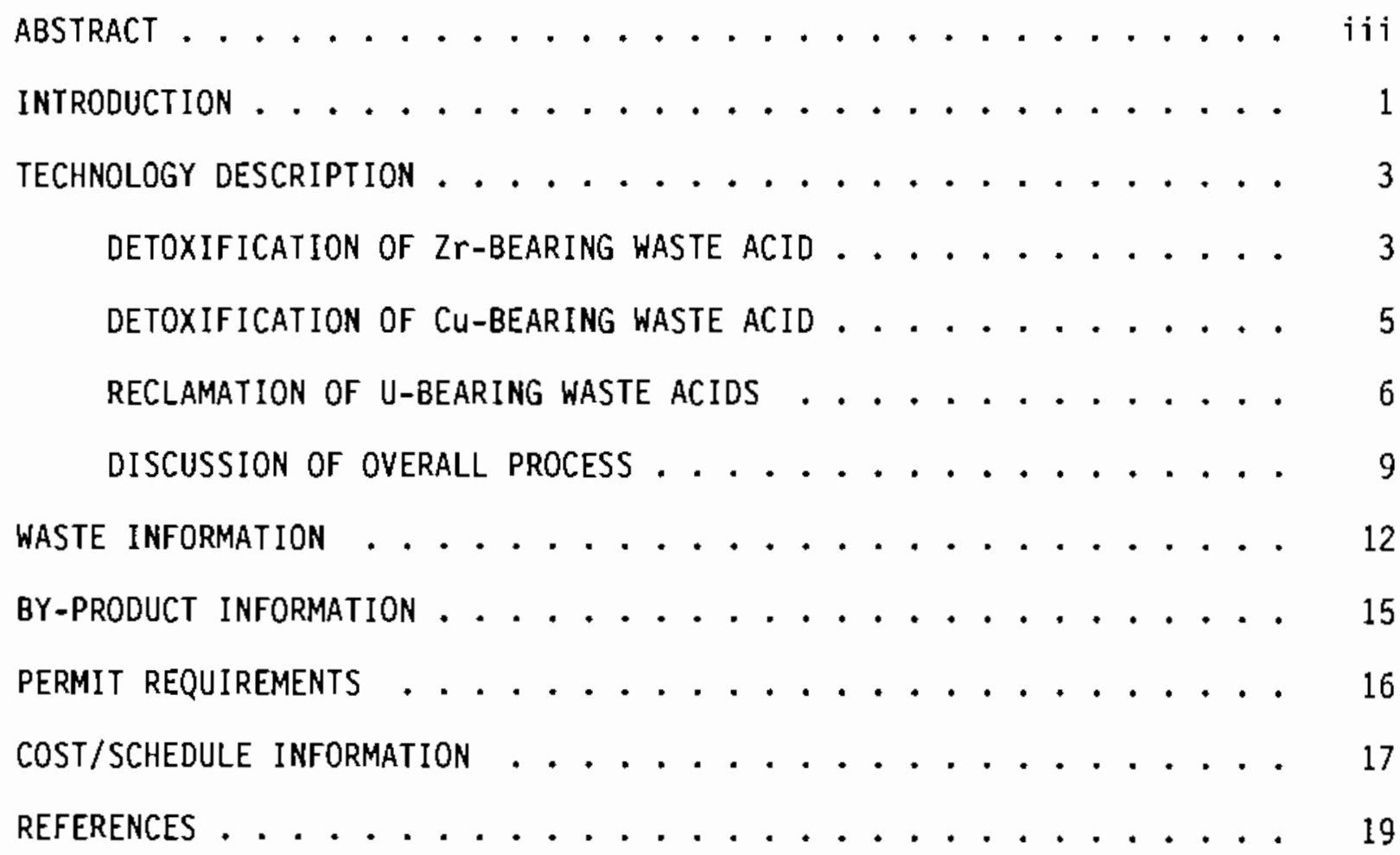




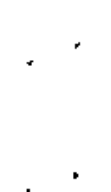




\section{FIGURES}

1 Proposed Acid Distillation Process ............ 8

2 Projected volume Reductions .............. 9

3 Projected Payback Periods . . . . . . . . . . . . . 10

4 Schematic of Current Fuel Fabrication Process . . . . . . . 12

\section{TABLES}

1 Average Annual Composition of Discharged Metal-Finishing

Process Streams ................... 


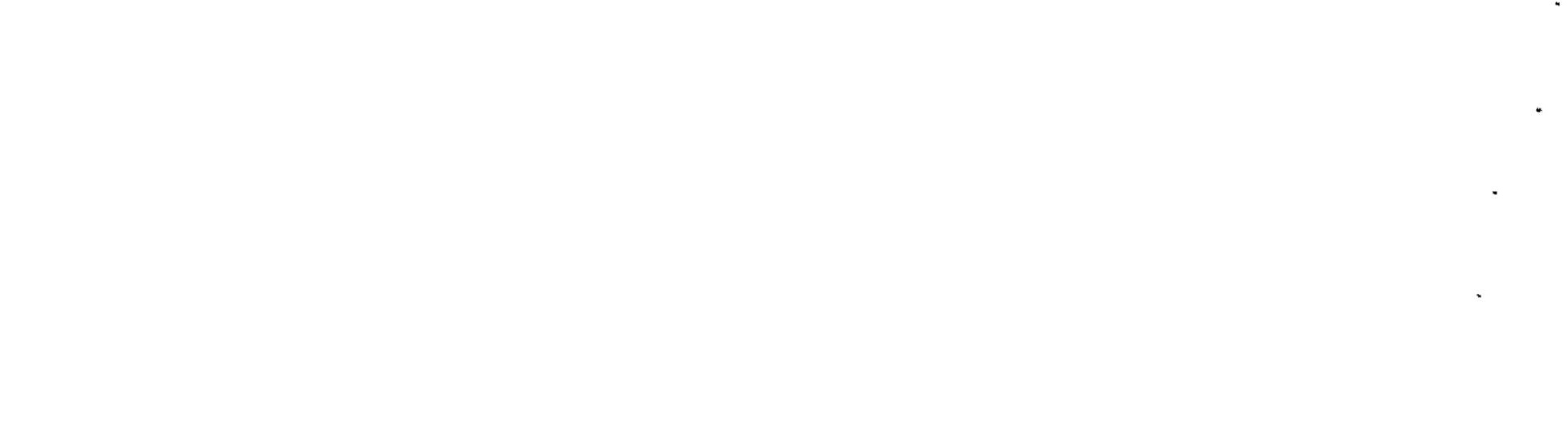




\section{INTRODUCTION}

Since 1976, the U.S. Environmental Protection Agency (EPA) has encouraged generators of hazardous waste to prioritize waste management practices as follows: source reduction, recycle, waste stream treatment, and land disposal. This philosophy was incorporated into the 1984 Hazardous and Solid Waste Amendments (HSWA) to the Resource Conservation and Recovery Act (RCRA) that now requires hazardous waste generators to certify that a waste minimization program, which can include source reduction, recycling, or treatment, is being implemented at their facility. In general, the initial response by generators has been to conduct waste audits to better identify the type and sources of waste generated. Subsequent procedural changes within the operations can then be implemented to reduce waste; these changes can be made with low or no capital investment and with a minimal impact on operating costs. To further reduce the volume of waste generated, more capital-intensive measures for source reduction will need to be implemented. These expenditures can be justified based on reduced materials, disposal, and long-term liability costs.

The technology described in this document is a waste source reduction technique that can be applied to metal-bearing acids frequently generated during metal refining, metal finishing, and electroplating operations. The nuclear, aerospace, electronics, and steel and specialty metals industries commonly produce waste acid solutions such as $\mathrm{HNO}_{3}, \mathrm{HF}, \mathrm{HCl}$, and $\mathrm{H}_{2} \mathrm{SO}_{4}$ contaminated with heavy metals such as $\mathrm{Zr}, \mathrm{Cu}, \mathrm{Al}, \mathrm{Ni}, \mathrm{Cr}$, and $U$. Past treatment and disposal practices have included neutralization and discharge to solar evaporation ponds. This disposal technique is no longer environmentally acceptable. A waste management option is to reduce the volume, quantity, and toxicity of the waste acid at the source by concurrently removing heavy metals for reuse or disposal and regenerating acid for recycle.

The objective of the Waste Acid Detoxification and Reclamation (WADR) project is to adapt and demonstrate processes and process equipment that reduce the volume, quantity, and toxicity of metal-bearing waste acids. The goal is to use techniques to detoxify the acid by removing heavy metals and to reclaim 
acid for recycle. The overall effect is a reduction of the volume of waste requiring disposal, subsequently reducing the potential hazard to the environment, the cost of raw materials, and the cost for disposal.

The approach to be taken to meet this objective includes conducting benchscale tests to collect engineering data, designing and installing a pilotscale system based on these data, and operating the pilot-scale system to demonstrate the process on actual spent acid solutions. The project duration is estimated to be five years (dependent on funding levels). The project was initiated in fiscal year (FY) 1986. At this time (FY 1988), bench-scale testing is near completion and the pilot-scale system has been designed and is being procured.

This project planning document will be used as a planning tool for completion of the work that has been initiated. It includes a description of the technology, waste stream information, by-product information, permit requirements, and cost/schedule information. 


\section{TECHNOLOGY DESCRIPTION}

The processes being adapted for detoxification and reclamation of waste acids include two precipitation processes to remove heavy metals while concurrently regenerating acid for recycle and a distillation process to regenerate the acid solution for recycle. The waste streams chosen for demonstration of WADR consisted of $\mathrm{Zr}$-bearing $\mathrm{HNO}_{3}-\mathrm{HF}$, Cu-bearing $\mathrm{HNO}_{3}$, and U-bearing $\mathrm{HNO}_{3}-\mathrm{H}_{2} \mathrm{SO}_{4}$. These spent acids are generated from chemical etching, stripping, and milling operations, respectively, that are used in the fabrication of fuel rods at the Hanford Site (see section on Waste Stream Information). Candidate methods for detoxification and reclamation of each waste stream were discussed in reports by Wick, Elmore, and Hartley (1983), Weakley (1984), and Stewart and Hartley (1985). These methods included precipitation, electrowinning, resin bed exchange, distillation, and membrane separation. Precipitation processes for $\mathrm{Zr}$ and $\mathrm{Cu}$ removal and a distillation process to recover $\mathrm{HNO}_{3}$ and $\mathrm{HF}$ were chosen based on:

- technical and economic feasibility

- compatibility with disposal scenario

- compatibility with current operating procedures and available space

- availability of commercial equipment.

Further discussion on the candidate methods for detoxification and reclamation of spent acid and a description of the process will be discussed for each of the three streans in the following subsections.

\section{DETOXIFICATION OF Zr-BEARING WASTE ACID}

Precipitation methods based on the formation of insoluble fluorozirconates in mixed acid solutions containing $17 \mathrm{~g} / \mathrm{L} \mathrm{HF}$ and $400 \mathrm{~g} / \mathrm{L} \mathrm{HNO}$ are proposed for detoxification of the etching solutions containing $\mathrm{Zr}$. Several $\mathrm{Na}$ and $\mathrm{Ca}$ compounds $\mathrm{can}$ be used to remove $\mathrm{Zr}$ from this acid solution; $\mathrm{CaF}_{2}$, $\mathrm{Ca} 0$, $\mathrm{CaCO}_{3}, \mathrm{Ca}(\mathrm{OH})_{2}, \mathrm{NaF}, \mathrm{NaOH}$, and $\mathrm{NaNO}_{3}$ were identified as candidate precipitants. The use of $\mathrm{NaF}$ and $\mathrm{NaOH}$ for $\mathrm{Zr}$ removal are described in two patents (Megy et al. 1978 and Fenneman 1981, respectively). In addition, two producers of $\mathrm{Zr}$ products in the Northwest have experience with the use of $\mathrm{NaF}$ precipitation. Both have reported operating problems associated with 
solid/liquid separation characteristics of the slurry, and equipment problems resulting from delayed precipitation in pipes, pumps, and storage tanks.

Precipitation of $\mathrm{Na}_{2} \mathrm{ZrF}_{6}$ using $\mathrm{NaF}$ was chosen over other possible candidates because the subsequent reaction did not introduce the potential for fouling from $\mathrm{Ca}$, reduction in the quantity of $\mathrm{HF}$ through reaction with $\mathrm{Ca}$, or reduction in $\mathrm{HF}$ concentration due to formation of $\mathrm{H}_{2} \mathrm{O}$ using $\mathrm{NaOH}$. Although operating problems had been reported using $\mathrm{NaF}$, it was believed that further testing could help identify operating conditions that would avoid these problems. In addition, laboratory tests also indicated that NaF reduced the concentration of dissolved $\mathrm{Zr}$ at room temperature and increased the quantity of HF. The precipitation reaction is shown in Equation (1).

$$
\mathrm{H}_{2} \mathrm{ZrF}_{6}+2 \mathrm{NaF}(\mathrm{s})=\mathrm{Na}_{2} \mathrm{ZrF}_{6}(\mathrm{~s})+2 \mathrm{HF}
$$

Bench-scale tests were needed to identify operating conditions such as reaction temperature, stoichiometric addition of NaF, stirring speeds, and length of crystallization period to ensure both acceptable removal of $\mathrm{Zr}$ and acceptable solid/liquid separation characteristics of the slurry to avoid the problems experienced by industry.

These bench-scale tests indicated that a reaction temperature of $20^{\circ} \mathrm{C}$, stoichiometric addition of $\mathrm{NaF}$ at $0.83 \mathrm{~g} / \mathrm{g} \mathrm{Zr}$, impeller tip speeds of $320 \mathrm{~cm} / \mathrm{sec}$, and a 24-h crystallization period could be used. The equipment used in this process included a conical bottom mix tank with a heat exchange unit and low/moderate shear impeller, diaphragm pump, and filter press. All wetted surfaces must be polypropylene, fluoropolymers, or polyvinyl chloride (for low-temperature service). The process includes the following steps: 1) charge the reaction/mix tank with spent acid from the etching operation, 2) add solid NaF using the mixer during reaction, 3) discontinue mixing during the 24-h crystallization period, 4) resuspend the slurry after crystallization, and 5) transfer the slurry to the filter press for solid/ liquid separation.

The resulting filtrate can then be recycled as an enriched HF solution, and the zirconate salt (sodium hexafluorozirconate) could be sold to the aluminum industry as a by-product for alloying or could be disposed as a 
hazardous waste after neutralization and dewatering. Eventually the concentration of heavy metals other than $\mathrm{Zr}$ will exceed acceptable operating levels and the etch solution will require further treatment. This spent solution will be detoxified using the precipitation process and mixed with the spent milling solution for reclamation using distillation.

\section{DETOXIFICATION OF CU-BEARING WASTE ACID}

Methods studied for removing $\mathrm{Cu}$ from a solution of $\mathrm{HNO}_{3}$ at concentrations of 3.5 to $4.5 \mathrm{M}$ at the time of discharge included membrane separation, resin bed exchange, electrowinning, and precipitation. Although effective for separation, ion transfer membranes required large surface contact areas and high capital investment. Resin beds produced large aqueous waste streams, thereby reducing the incentive for detoxification. After initial screening and elimination of membrane and resin bed techniques, electrowinning and precipitation were evaluated in greater detail. Although high-current-density electrowinning is technically feasible in removing Cu metal from solution, it requires lower operating temperatures to adequately reduce the competing chemical dissolution reactions. The cost of a refrigeration system to obtain Cu separation and the low market value of Cu makes electrowinning economically unfeasible. A low-current-density electrowinning process that uses sulfamic acid to reduce the rate of the competing chemical dissolution was described in a patent (Mockrin and Hobin 1977). However, it could not be used because sulfamic acid introduces sulfate ions into the recycled strip solution, which causes premature milling of exposed $U$ metal.

Precipitation reactions, however, can be used to form insoluble $\mathrm{Cu}$ compounds such as $\mathrm{CuC}_{2} \mathrm{O}_{4}, \mathrm{CU}(\mathrm{OH})_{2}, \mathrm{CuS}$, and $\mathrm{CuCO}_{3}$ which can be separated from solution. The addition of either $\mathrm{Na}_{2} \mathrm{C}_{2} \mathrm{O}_{4}$ or $\mathrm{H}_{2} \mathrm{C}_{2} \mathrm{O}_{4}$ to Cu-bearing acid solutions results in the formation of an insoluble copper oxalate. Based on technical considerations, these reactions were chosen over the formation of hydroxide, sulfide, or carbonate precipitants. Although both sodium oxalate and oxalic acid produce a $\mathrm{CuC}_{2} \mathrm{O}_{4}$ precipitant when added to Cu-bearing $\mathrm{HNO}_{3}$ solutions, oxalic acid addition allows regeneration of $\mathrm{HNO}_{3}$ as shown in Equation (2). 


$$
\mathrm{Cu}\left(\mathrm{NO}_{3}\right)_{2}+\mathrm{H}_{2} \mathrm{C}_{2} \mathrm{O}_{4}(\mathrm{~s})=\mathrm{CuC}_{2} \mathrm{O}_{4}(\mathrm{~s})+2 \mathrm{HNO}_{3}
$$

The proposed precipitation process has not been used commercially; therefore, bench-scale tests were required to determine operating conditions such as reaction temperature, initial $\mathrm{Cu}$ concentration, length of crystallization, use of seed slurry (to improve particle growth rates) to achieve both acceptable Cu removal and acceptable solid/liquid separation characteristics.

These bench-scale tests indicated that reaction temperatures of $60^{\circ} \mathrm{C}$, initial $\mathrm{Cu}$ concentrations of 100 to $180 \mathrm{~g} / \mathrm{L}$, and a crystallization period of $24 \mathrm{~h}$ could be used. Furthermore, seed slurry did not improve the rate of particle growth and need not be used.

The equipment used for this process is the same as that used for $\mathrm{Zr}$ precipitation: a heated and stirred mix tank, diaphragm pump, and filter press. The process includes the following steps: 1) charge the mix tanks with spent acid from the stripping operation, 2) heat the spent acid, 3) add solid oxalic acid using the mixer during reaction, 4) discontinue mixing during the crystallization period, 5) resuspend the slurry, and 6) transfer the slurry via the pump to the filter press for solid/liquid separation.

As $\mathrm{Cu}$ is removed from solution, $\mathrm{HNO}_{3}$ is regenerated and can, therefore, be recycled to the metal-finishing process. Irreversible dilution of the acid does occur during the metal stripping operation because of conversion of $\mathrm{HNO}_{3}$ to $\mathrm{NO}_{\mathrm{x}}$ rather than $\mathrm{Cu}\left(\mathrm{NO}_{3}\right)_{2}$. Therefore, at a specified $\mathrm{HNO}_{3}$ concentration (approximately $3 \mathrm{M} \mathrm{HNO}_{3}$ ) the Cu-bearing $\mathrm{HNO}_{3}$ would require discharge. This solution will be detoxified using the precipitation step and mixed with the spent milling solution for reclamation using distillation. The $\mathrm{CuC}_{2} \mathrm{O}_{4}$ precipitate will be neutralized and dewatered using absorbent material to meet waste packaging requirements. Heat generated during neutralization will themally degrade $\mathrm{CuC}_{2} \mathrm{O}_{4}$ to a less toxic CuO for disposal.

\section{RECLAMATION OF U-BEARING WASTE ACIDS}

Two methods were considered for reclamation of U-bearing waste acids: membrane separation and distillation with $\mathrm{H}_{2} \mathrm{SO}_{4}$. Because of technical concerns, 
the membrane separation method was eliminated from consideration during the screening process. Distillation with $\mathrm{H}_{2} \mathrm{SO}_{4}$ of the mixed acid stream containing $270 \mathrm{~g} / \mathrm{L} \mathrm{HNO} 3,450 \mathrm{~g} / \mathrm{L} \mathrm{H}_{2} \mathrm{SO}_{4}$, and $62 \mathrm{~g} / \mathrm{L} \mathrm{U}$ was chosen for reclamation of $\mathrm{HNO}_{3}$ from free $\mathrm{HNO}_{3}$ and nitrate salts present in the spent milling stream (i.e., U-bearing waste acid). In addition, this technique can be used to reclaim $\mathrm{HNO}_{3}$ and $\mathrm{HF}-\mathrm{HNO}_{3}$ from the detoxified etch and strip solutions.

Normally, $\mathrm{HNO}_{3}$ remains in the bottoms when an aqueous acid solution is distilled; however, in the presence of $\mathrm{H}_{2} \mathrm{SO}_{4}, \mathrm{HNO}_{3}$ will distill to the overhead stream. This technique is used in the $\mathrm{HNO}_{3}$ production industry to bind water and allow nitric acid to be concentrated above its azeotrope at $68.5 \mathrm{wt} \%$ $\mathrm{HNO}_{3}$. Typically a mixture of about 50 to $60 \mathrm{wt} \% \mathrm{H}_{2} \mathrm{SO}_{4}$ and aqueous $\mathrm{HNO}_{3}$ is distilled to produce concentrated $\mathrm{HNO}_{3}(90+\mathrm{wt} \%)$ in the overhead vapor. The goal is to adapt this technology for use in reclaiming spent acid, primarily from the chemical milling operation, for recycle. The chemical milling stream contains $33 \mathrm{wt}_{\%} \mathrm{H}_{2} \mathrm{SO}_{4}$. Distillation of this stream results in an aqueous $\mathrm{HNO}_{3}$ solution with a concentration suitable for metal-finishing operations (i.e., 57 wt\%) that is free of impurities, because heavy metals including $U$, solids, and other contaminants are retained in the $\mathrm{H}_{2} \mathrm{SO}_{4}$ bottoms liquid. Uranium can be recovered in a downstream neutralization step and refined for reuse.

As shown in Figure 1, the acid mixture is fed to a $\mathrm{HNO}_{3}$ boiler where water and $\mathrm{HNO}_{3}$ are separated from $\mathrm{H}_{2} \mathrm{SO}_{4}$. Heavy contaminants and $\mathrm{H}_{2} \mathrm{SO}_{4}$ collect in a bottoms holding tank for later neutralization and separation, while greater than $50 \%$ of the original acid solution volume is vaporized to a packed distillation column. Traditional nitric acid rectification occurs in this acid column to concentrate the water and $\mathrm{HNO}_{3}$ that was flashed off the reboiler. Water is vaporized to the condenser and $\mathrm{HNO}_{3}$ collects in the reboiler and is transferred to a bottoms hold tank. The reclaimed $\mathrm{HNO}_{3}$ is suitable for recycle to any of the metal-finishing operations and the distilled water can be used as make-up water for other processes. 


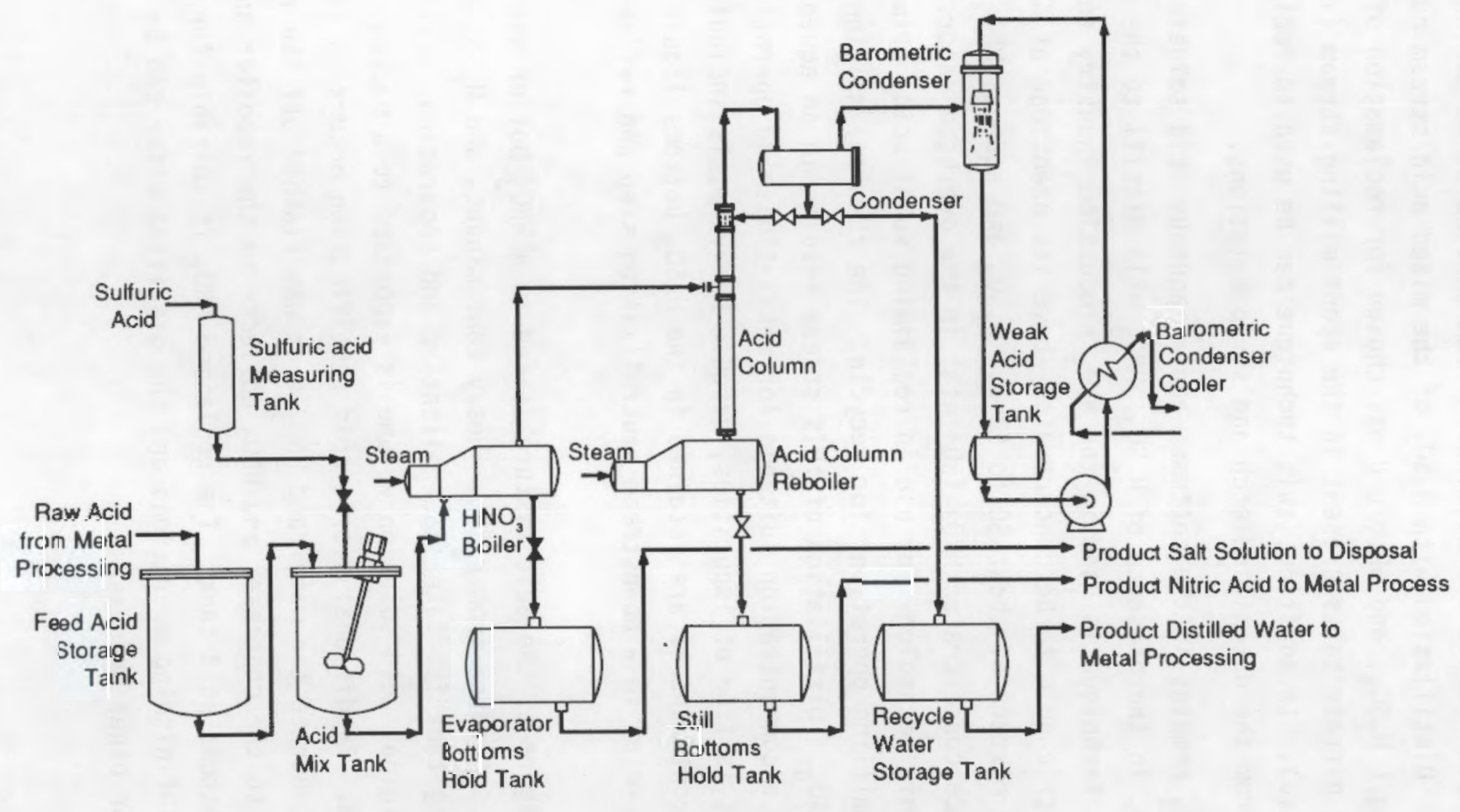

FIGURE 1. Proposed Acid Distillation Process 
This process can also be used to reclaim the $\mathrm{HF}-\mathrm{HNO}_{3}$ etch solution that can no longer be recycled due to concentration of minor metal impurities. Volatile $\mathrm{HF}$ is carried into the column with $\mathrm{HNO}_{3}$ from the reboiler. To withstand the attack of a highly corrosive ternary mixture of $\mathrm{HF}-\mathrm{HNO}_{3}-\mathrm{H}_{2} \mathrm{SO}_{4}$, standard processing equipment cannot be used. Wetted surfaces of the process equipment must consist of a fluoropolymer suitable to high-temperature mixedacid conditions. A recycling condenser/scrubber system is also included to retain any volatilized HF. When the concentration of acid in the scrubber water becomes elevated, this stream can also be processed through the distillation system.

\section{DISCUSSION OF OVERALL PROCESS}

Precipitation of primary metal contaminants and distillation of $\mathrm{HNO}_{3}$ are used to detoxify and reclaim acids from the metal-finishing operations used in fuel fabrication. The annual volume of acid requiring neutralization and disposal can be reduced when these technologies are included in the metal finishing process. As shown in Figure 2, the precipitation reactions result

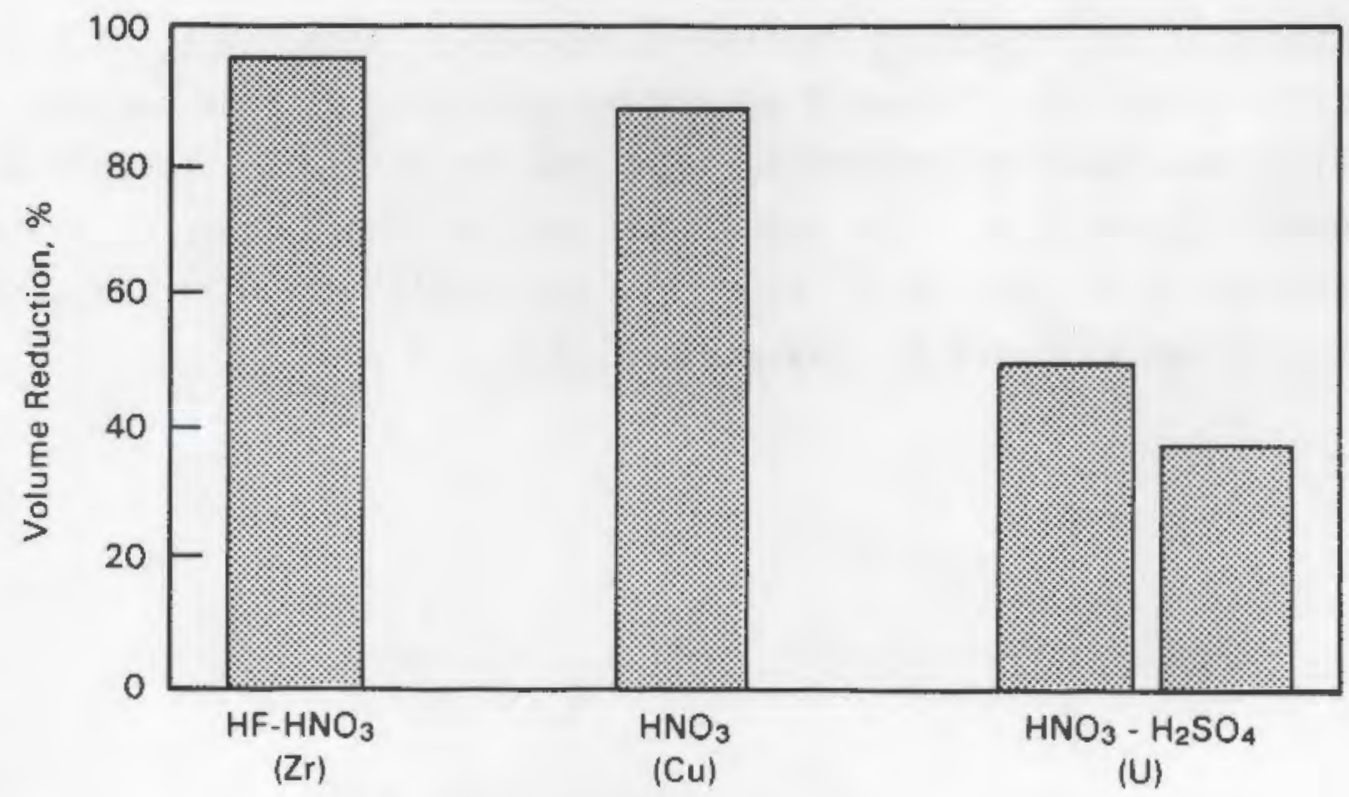

FIGURE 2. Projected Volume Reductions 
in one-pass volume reductions greater than $90 \%$. Eventually, metal contaminants other than $\mathrm{Zr}$ and $\mathrm{Cu}$ will concentrate above acceptable operating limits and these process streams will require distillation to recover $\mathrm{HNO}_{3}$ and remove metal contaminants. Depending on the $\mathrm{H}_{2} \mathrm{SO}_{4}$ concentration, distillation can reduce the volume of acid discharged for treatment by as much as $60 \%$. As a result the volume and quantity of acid requiring neutralization will be significantly reduced. In addition, removal of the heavy metals from these solutions reduces toxicity.

The 1984 HSWA amendments to RCRA encourage these types of waste minimization efforts as a means of hazardous waste management. Specifically, reduction of hazardous waste at the source, reuse or recovery of useful components, and minimization of the volume and toxicity of waste are emphasized as primary methods for eliminating hazardous wastes. This approach to waste management is supported by environmental groups and is generally considered socially acceptable. Under these guidelines, the WADR processes constitute methods of waste minimization and are therefore both acceptable and encouraged as a waste management practice. The process is not regulated as a treatment process because it uses internal process streams rather than the final waste stream.

In addition to regulatory compliance and social acceptance, WADR is economically justified. Figure 3 identifies projected payback periods based on installed equipment and operating costs and savings from recovered acid and reduced disposal cost. The payback period for $\mathrm{Zr}$ and $\mathrm{Cu}$ precipitation processes are $0.6 \mathrm{yr}$ and $1.3 \mathrm{yr}$, respectively. Distillation of the U-bearing $\mathrm{H}_{2} \mathrm{SO}_{4}-\mathrm{HNO}_{3}$ stream will yield a payback period of $2.2 \mathrm{yr}$. 


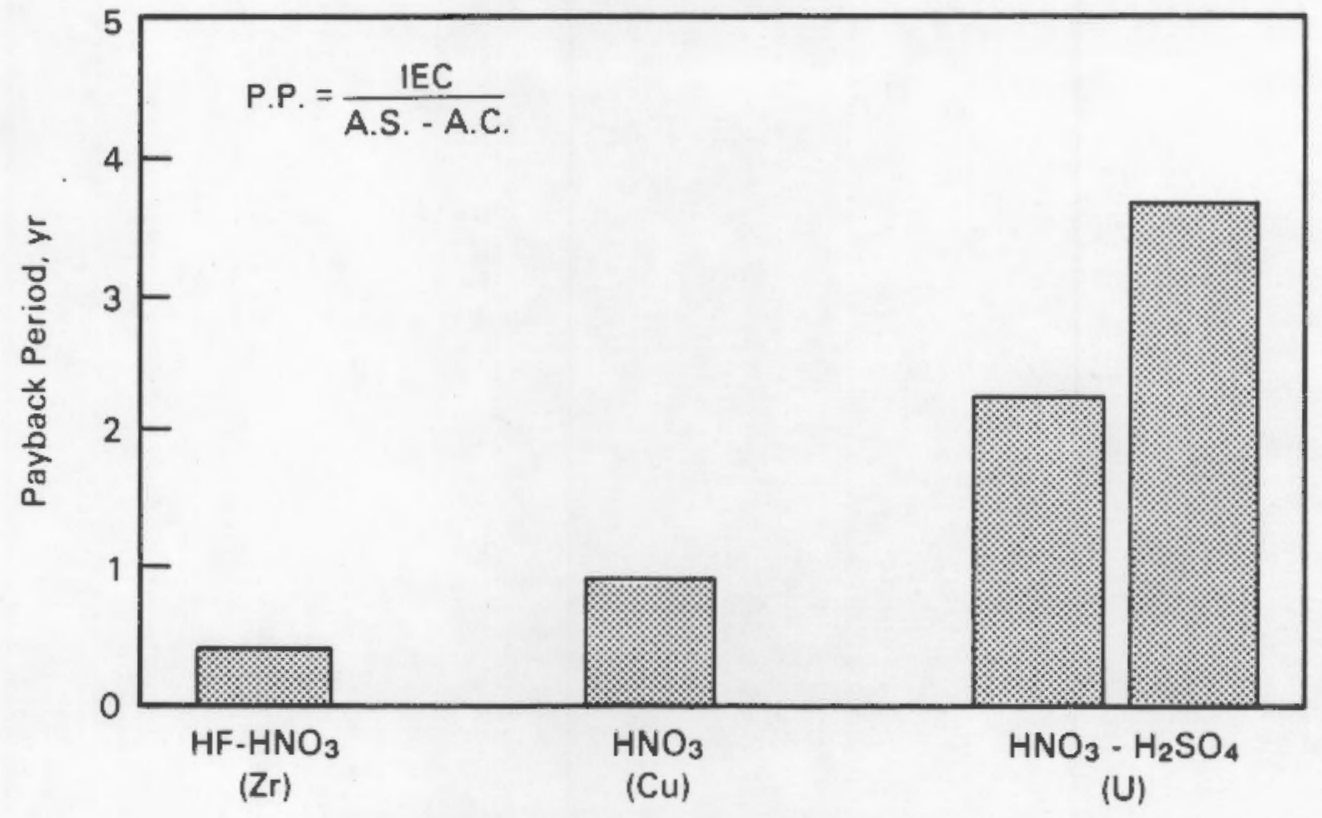

FIGURE 3. Projected Payback Periods 



\section{WASTE INFORMATION}

The waste process streams chosen for demonstration of the detoxification and reclamation processes are generated at Hanford during nuclear fuel fabrication. Fuel fabrication is a series of metal-finishing operations in which acid solutions are used for chemical milling, etching, and stripping of fuel assembly materials. Currently, the acid solutions are discharged as the concentration of one major metal impurity exceeds acceptable operating limits and then are sent to downstream treatment and disposal, as shown in Figure 4. Until late 1985, the neutralized wastes were discharged to solar evaporation ponds.

When discharged, the process streams contain a high concentration of acid, a high concentration of one major metal impurity, and very dilute concentrations of several minor metal impurities introduced from the metal alloys used in fuel assemblies. Specifically, the chemical milling solution contains $\mathrm{HNO}_{3}-\mathrm{H}_{2} \mathrm{SO}_{4}$, with $\mathrm{U}$ as the major metal impurity. The etch solution contains $\mathrm{HF}_{-} \mathrm{HNO}_{3}$ with $\mathrm{Zr}$ as the major metal impurity, and the strip solution contains $\mathrm{HNO}_{3}$ with $\mathrm{Cu}$ as the major metal impurity. The average annual composition and quantity of the three process streams are shown in Table 1.

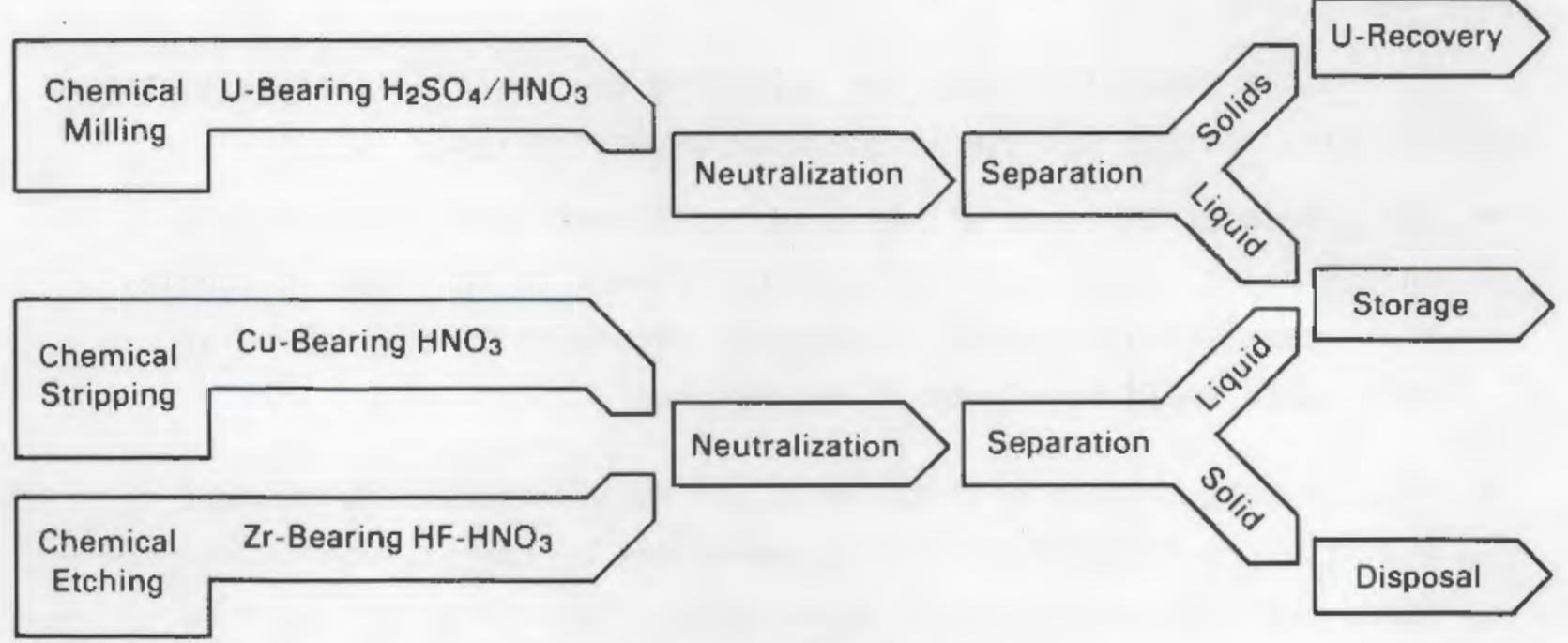

FIGURE 4. Schematic of Current Fuel Fabrication Process 
TABLE 1. Average Annual Composition of Discharged Metal-Finishing Process Streams

\begin{tabular}{|c|c|c|c|c|c|c|c|c|}
\hline \multirow[b]{2}{*}{ Stream } & \multicolumn{7}{|c|}{ Composition, wt\% (a) } & \multirow{2}{*}{$\begin{array}{c}\text { Volume, } \\
\text { L/yr }\end{array}$} \\
\hline & $\mathrm{HNO}_{3}$ & $\underline{\mathrm{H}_{2} \mathrm{SO}_{4}}$ & $\mathrm{HF}$ & $U$ & $\mathrm{Zr}$ & $\mathrm{Cu}$ & $\mathrm{H}_{2} \mathrm{O}$ & \\
\hline Chemical Milling & 19.9 & 33.2 & -- & 4.6 & -- & -- & 42.3 & 129,700 \\
\hline Zr-Etching & 40.5 & $\cdots$ & 2.0 & -- & 3.6 & -- & 53.8 & 161,000 \\
\hline Cu-Stripping & 20.7 & 0.3 & 0.5 & -- & -- & 9.4 & 68.6 & 185,100 \\
\hline
\end{tabular}

(a) Process streams contain trace quantities of $\mathrm{Cr}, \mathrm{Si}, \mathrm{Fe}, \mathrm{Ni}, \mathrm{Al}$, etc.

Approximately $750,000 \mathrm{~L} / \mathrm{yr}$ of waste slurry is generated after neutralizing the waste acid and then disposal separating the residual solids. Uranium is recovered from the chemical milling solution as a sodium diuranate after neutralization. The solids, primarily precipitated metal salts, are drummed and sent to a landfill, whereas the liquid wastes are transported to doubleshell tanks for storage. Grouting of the liquid waste slurry has been proposed to reduce the mobility of nitrates, fluorides, and metals. Treatment of these streams must meet RCRA and Washington State regulations (WAC 173-303). However, the minimization processes proposed in this project, detoxification and reclamation, are not regulated because they are internal recycle operations that avoid waste generation.

There were several reasons for selecting the waste acid process streams from fuel fabrication for use in the WADR demonstration:

- The volume of the neutralized acid discharged from the process is on the order of $10^{6} \mathrm{~L} / \mathrm{yr}$ and will contribute to the load on doubleshell tank storage space. Therefore, reduction in the volume of this waste would have a positive impact.

- These wastes contain nitrates that are mobile in the environment and will require additional considerations or constraints on performance criteria for the final waste form. Therefore, it would be desirable to reduce or eliminate nitrates from the waste stream. 
- Fuel fabrication streams are amenable to detoxification and reclamation processes because their composition is relatively constant and the volume for each type of stream is great enough (i.e., on the order of $200,000 \mathrm{~L} / \mathrm{yr}$ ) to make this approach feasible.

- Because $\mathrm{HNO}_{3}$ is commoniy used in the nuclear industry, demonstration of a method for reducing the volume of nitrate wastes would be transferrable to or supportive of the development of similar efforts for other waste process streams at DOE facilities. In addition to Hanford, low-level nitrate wastes are generated at Rocky Flats, Oak Ridge, Los Alamos, and Fernald. Approximately $10^{4}$ to $10^{5} \mathrm{~kg} \mathrm{NO}_{3}^{-}-\mathrm{N} / \mathrm{yr}$ are generated at each facility (Johnson et al., 1982). Similar types and volumes of nitrate wastes are also generated at Savannah River Plant, where fuel fabrication operations also exist. Distillation with $\mathrm{H}_{2} \mathrm{SO}_{4}$ could be considered at facilities where nitric acid reclamation through distillation was discounted because of expected impurity problems. In the proposed process, contaminants are separated from the acid rather than concentrated with the $\mathrm{HNO}_{3}$. Facilities recovering nitric acid by other methods or treating nitrate wastes from nitric acid processes could consider acid distillation as an alternative. 
- 


\section{BY-PRODUCT INFORMATION}

The waste acid detoxification and reclamation process produces two new by-product streams and a waste stream with reduced volume. A solid fluorozirconate salt $\left(\mathrm{Na}_{2} \mathrm{ZrF}_{6}\right)$ is produced from detoxification of the etching solution and a copper oxalate $\left(\mathrm{CuC}_{2} \mathrm{O}_{4}\right)$ precipitate is formed from detoxification of the stripping solution. Ireatment of these precipitants is discussed below. A neutralized sulfate waste stream contaminated with metals such as $\mathrm{Si}$, Fe, $\mathrm{Ni}, \mathrm{Cr}$, and $\mathrm{Al}$ is also produced but with much less volume than the current neutralized waste stream. This process waste stream is stored in double-shell tanks until final disposal as a grout to minimize transport of residual metal constituents.

The $\mathrm{Zr}$ and $\mathrm{Cu}$ precipitates must be neutralized by mixing with solid $\mathrm{NaOH}$ to retard any residual acid. Heat generated during neutralization will thermally degrade $\mathrm{CuC}_{2} \mathrm{O}_{4}$ to a less toxic CuO. The $\mathrm{Na}_{2} \mathrm{ZrF}_{6}$ is used in the aluminum industry for alloying and could be sold for this purpose if generated from a process that did not contact nuclear material. After neutralizing, the precipitates can be disposed to secure landfills after proper packaging with absorbent materials. In the future, these solids may be considered radioactive mixed wastes. The current, applicable regulations for treating and disposing of these waste solids may include 40 CFR 261 (RCRA), WAC 173-303, and DOE 5820.2. 



\section{PERMIT REQUIREMENTS}

The waste acid detoxification and reclamation process uses fuel fabrication internal process streams rather than waste streams. Therefore, WADR is not regulated as a treatment process and does not require special permits. 


\section{COST/SCHEDULE INFORMATION}

The WADR concept will be developed from bench-scale evaluation through pilot-scale demonstration over a five year period, depending on availability of funding. Five tasks have been identified: 1) program management to provide coordination and reporting, 2) bench-scale studies to adapt precipitation and distillation techniques for waste acid detoxification and reclamation, 3) engineering development and design to determine process equipment requirements, 4) pilot-plant procurement and installation, and 5) pilot-plant operation to determine performance and economics of the proposed process. The overall cost is estimated as $\$ 1,660 \mathrm{~K}$ for operation plus capital equipment costs of $\$ 59 \mathrm{~K}, \$ 120 \mathrm{~K}$, and $\$ 115 \mathrm{~K}$ for $\mathrm{FY} 1987,1988$, and 1989 , respectively. The work breakdown and associated costs are listed below.

\section{FY 1986}

Cost: $\$ 170 \mathrm{~K}$

Activity: Complete bench-scale precipitation tests and design of the bench-scale distillation test loop.

Status: Completed.

\section{FY 1987}

Cost: $\$ 250 \mathrm{~K}$

Activity: Conduct bench-scale distillation and materials of construction tests. Design pilot-plant equipment.

Status: Completed first phases of 100-day tests on construction materials and laboratory-scale distillation tests. Completed startup of bench-scale test loop and initiated distillation tests on this unit. Completed pilot-scale distillation equipment design. 
FY 1988 (Current Fiscal Year)

Cost: $\$ 250 \mathrm{~K}$

Activity: Complete bench-scale distillation tests. Procure distillation pilot-plant equipment and continue pilot-plant design. Initiate installation.

Status: Continued bench-scale distillation tests and initiated procurement of pilot-plant equipment. Pilot-plant design is extended through FY 1989 because of lower than expected funding levels in FY 1988.

\section{FY 1989}

\section{Cost: $\$ 440 \mathrm{~K}$}

Activity: Complete startup of distillation pilot plant and initiate distillation demonstration. Design, procure, and initiate installation of precipitation pilot plant equipment.

\section{$\underline{\text { FY } 1990}$}

\section{Cost: $\$ 450 \mathrm{~K}$}

Activity: Complete distillation and precipitation pilot plant operation. Complete economic evaluation and technology transfer documentation. 


\section{$\underline{\text { REFERENCES }}$}

Fenneman, $W$. "Verfahren zum Regenerieren von $\mathrm{ZrF}_{4}$ Enthaltenden Beizlosungen," German Patent DE 3009265, 1981.

Johnson, A. J., L. J. Meile and G. F. Jaskot. 1982. Commercial and Defense Nitrate Wastes and Processing Alternatives. RFP-3282, Rockwell International, Rocky Flats Plant, Golden, Colorado.

Mockrin, I., and M. Hobin. "Recovery of Copper from Waste Nitrate Liquors by Electrolysis," U.S. Patent 4033838, 1977.

Megy, J. A., and R. L. Propst. "Process for Regenerating a Pickle Acid Bath," U.S. Patent $4105469,1978$.

Stewart, T. L., and J. N. Hartley. Evaluation of Improved Chemical Waste Disposal and Recovery Methods for $N$ Reactor Fuel Fabrication Operations: 1984 Annual Report. PNL-5294 (UNI-3204), Pacific Northwest Laboratory, Richland, Washington.

Weakley, E. A. 1984. Improved Chemical Waste Disposal Methods for Fuels Qperations. UNI-3026, UNC Nuclear Industries, Richland, Washington.

Wick, 0. J., M. R. Elmore and J. N. Hartley. 1983. Review of Process Options for Cleanup and Rejuvenation of Fuel Fabrication Process Solutions. PNL-4853. Pacific Northwest Laboratory, Richland, Washington. 

PNL-6507

DOE/HWP-5D

UC -69

\section{DISTRIBUTION}

No. of

Copies

10 DoE/Office of Scientific and Technical Information

R. E. Adams

U.S. DOE-HAZWRAP

P.0. BoX $Y$

Building 9108, MS 002

0ak Ridge, TN 37831

J. L. Epler

U.S. DOE-HAZWRAP

P.0. BoX Y

Building 9108, MS 002

0ak Ridge, TN 37831

J. C. Parker

U.S. DOE-HAZWRAP

P.0. BoX $Y$

Building 9108, MS 002

Oak Ridge, TN 37831

N. E. Rothermich

U.S. DOE-HAZWRAP

P.0. BoX $Y$

Building 9108, MS 002

Oak Ridge, TN 37831

R. J. Borkowski

U.S. DOE-HAZWRAP

P.0. BoX Y

FEDC Building

Oak Ridge, TN 37831

R. B. Craig

U.S. DOE-HAZWRAP

P.0. Box $Y$

FEDC Building

0ak Ridge, IN 37831
No. of

Copies

C. S. Fore

U.S. DOE-HAZWRAP

P.0. BoX $Y$

FEDC Building

Oak Ridge, TN 37831

P. J. Franco

U.S. DOE-HAZWRAP

P.0. BoX Y

FEDC Building

Oak Ridge, TN 37831

G. R. Jasny

U.S. DOE-HAZWRAP

P.0. BoX Y

FEDC Building

Oak Ridge, TN 37831

J. F. McBrayer

U.S. DOE-HAZWRAP

P.0. BoX $Y$

FEDC Building

Oak Ridge, TN 37831

J. L. Petty

U.S. DOE-HAZWRAP

P.0. Box $Y$

FEDC Building

Oak Ridge, TN 37831

J. S. Suffern

U.S. DOE-HAZWRAP

P.0. BOX $Y$

FEDC Building

Oak Ridge, TN 37831

W. W. Thompson

U.S. DOE-HAZWRAP

P.0. BoX Y

FEDC Building

Oak Ridge, TN 37831 
No. of

Copies

L. D. Eyman

U.S. DOE-HAZWRAP

P.0. BoX $Y$

FEDC Building

Oak Ridge, TN 37831

ONSITE

DOE Richland Operations Office

P. K. Clark
No. of

Copies

18 Pacific Northwest Laboratory

T. M. Brouns

T. L. Gilbride

J. N. Hartley

R. S. Kemper

T. L. Stewart (5)

J. L. Straalsund

P. C. Walkup

Publishing Coordination (2)

Technical Report Files (5) 